\title{
DHX58 Gene
}

National Cancer Institute

\section{Source}

National Cancer Institute. DHX58 Gene. NCI Thesaurus. Code C158446.

This gene is involved in modulation of antiviral response signaling. 